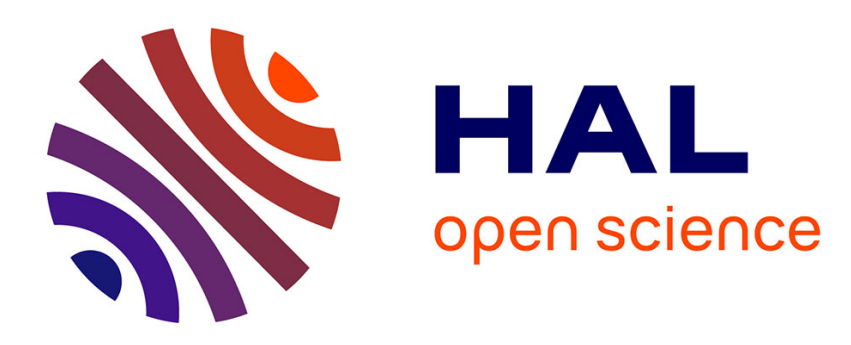

\title{
Increased farmer income evidenced by a new multifunctional actor network in China
}

\author{
Liaoji Zheng, Huiqing Liu
}

\section{To cite this version:}

Liaoji Zheng, Huiqing Liu. Increased farmer income evidenced by a new multifunctional actor network in China. Agronomy for Sustainable Development, 2014, 34 (2), pp.515-523. 10.1007/s13593-0130169-2 . hal-01234793

\section{HAL Id: hal-01234793 \\ https://hal.science/hal-01234793}

Submitted on 27 Nov 2015

HAL is a multi-disciplinary open access archive for the deposit and dissemination of scientific research documents, whether they are published or not. The documents may come from teaching and research institutions in France or abroad, or from public or private research centers.
L'archive ouverte pluridisciplinaire HAL, est destinée au dépôt et à la diffusion de documents scientifiques de niveau recherche, publiés ou non, émanant des établissements d'enseignement et de recherche français ou étrangers, des laboratoires publics ou privés. 


\title{
Increased farmer income evidenced by a new multifunctional actor network in China
}

\author{
Liaoji Zheng • Huiqing Liu
}

Accepted: 9 July 2013 / Published online: 31 July 2013

(C) INRA and Springer-Verlag France 2013

\begin{abstract}
Multifunctional agriculture is the core of sustainable agriculture because the suitable integration of multiple functions is a key for economically viable, environmentally safe, and socially equitable development in rural areas. Past investigations on multifunctional agriculture have mostly focused on the economy of multiple functions. There is scarce knowledge on structural relationships of multifunctional agriculture, notably in rural areas. To fill this gap, we used an analytical actor network to identify the structural relationships. Results show that the average income of farmers increased by $20 \%$ in multifunctional agriculture networks. Results also show that the actor network reached a state of equilibrium. We also build a structural equation model using interviews and participatory observations. Here, we incorporated data from 366 tourists, constituting $87.5 \%$ of those surveyed, and 52 local residents in Dalishu Village of Liaoning Province, China. Networking methods improved the efficiency of multifunctional agriculture by bridging ecology, tourism, society, and land use.
\end{abstract}

Keywords Multifunctional agriculture $\cdot$ Actor network theory $\cdot$ Structural equation model $\cdot$ Dalishu Village $\cdot$ China

L. Zheng $\cdot$ H. Liu $(\bowtie)$

College of Urban and Environmental Science, Northeast Normal

University, Changchun, Jilin Province 130024, China

e-mail: liuhq595@nenu.edu.cn

L. Zheng

e-mail: zhengliaoji@vip.sina.com

L. Zheng

School of Tourism \& Hospitality, Eastern Liaoning University, Dandong, Liaoning Province 118001, China

\section{Introduction}

\subsection{Impasse of multifunctional agriculture}

Multifunctional agriculture, as an important development engine, offers advantages for sustainable agriculture. The concept refers to the fact that agriculture, beyond its role in producing food and fiber, may also have several other functions such as renewable natural resource management, landscape, and biodiversity conservation. Agriculture can also contribute to protecting the lifestyle and cultural heritage of rural communities (Rossing et al. 2007; Wilson 2009). Most studies of multifunctional agriculture have remained fragmented regarding understanding the structural transition of its multiple functions (Renting et al. 2009; Granvik et al. 2012). The importance of multifunctional agriculture is significantly undervalued in these studies, which give no consideration to other functional values for competing effectively. Modern agriculture has high productivity and depends upon optimizing the productivity of monocultures and massive use of chemical inputs and fossil fuels. In this system, a strong economic function may weaken other functions in rural areas (Malézieux 2012). As a constraint on a sustainable agricultural ecosystem, multiple functions should achieve equilibrium between economic profitability, environmental safety, and social equity (Lichtfouse et al. 2009). However, multifunctional agriculture faces multiple socioeconomic changes, including a transition from an agriculture-based to service-based economy (Dessein et al. 2013). In this transition, multiple functions should correspond to the needs of the wider industry and reconfigure the rural landscape in ways that enhances the potential of sustainable agriculture. This results in difficult decision making when developing practicable strategies for 
multifunctional agriculture in land use. How to recognize the structural relationships of multiple functions in sustainable agriculture remains a problem in multifunctional agriculture.

Understanding the structural relations of multifunctional agriculture requires examination of the connections or relationships between landscape and agricultural factors, which may be represented as a network of links (Baggio et al. 2010). In general, the types of links include two main "bundles" of networks as follows: "vertical" networks that link the rural landscape to the agro-food sector and "horizontal" networks that link the rural landscape to more general and nonagricultural processes of economic change (Murdoch 2000). The construction of rural networks can affect the spatial configuration of multifunctional agriculture, which includes the following four types: agritourism, value-added production, direct sales, and off-farm income (Renting et al. 2009). However, an important question is how to identify relevant structural relationships of economic, environmental, tourism, and social functions for multifunctional agriculture in the rural network. The multifunctional agricultural system implies the consideration of change at larger scales, such as farm and regional scales, as well as creating feedback and facilitating participation of all stakeholders involved in the process (Le Bellec et al. 2012). Therefore, it is important to construct structural relationships for close integration of natural and social science aspects of factors in the construction of the multifunctional agriculture network.

\subsection{Need for a new paradigm of multifunctional agriculture}

The multifunctional agriculture actor network provides a new paradigm to integrate the human-nature structural relationship among multiple functions within a social method, which contributes to the wider goals of sustainable agriculture. Actor-network theory offers a framework focusing on the heterogeneous network of interactions between human and nonhuman actors, such as land use, rivers, folk customs, animals, and plants (Law 1992; Steen 2010). These actors are both market and nonmarket "function" factors of agriculture in rural areas (Refsgaard and Johnson 2010). Within the actor network, there is no subject-object hierarchy, only internal functionality (Noe et al. 2008).

As a spatial regulation of land use, tourism is a new function of multifunctional agriculture that relates to the goals of rural development, especially for new rural construction in China (Long et al. 2010). Multifunctional agriculture of new construction in rural areas also integrates rural policies that bring advanced production, improved livelihood, clean and tidy villages, a civilized social atmosphere, and efficient management. The actor network is an integrated method combining multiple goals of agriculture and pursues these with current or potential performance of multifunctional agriculture in rural areas. The multifunctional agriculture actor network is formed by interaction of geographic, ecological, societal, and industrial forces, which connect within and across various societies and regions, transport systems, accommodations and facilities, natural resources, rural environments, agricultural technologies, and villagers and organizations (Comber et al. 2003; Van der Duim 2007). Multiple functional activity contributes additional income to agriculture, which aids construction of a new agricultural sector that corresponds to the needs of the wider society. This activity must reconfigure rural resources in ways that enhance rural development benefits (Marsden and Sonnino 2008). Constructing a reasonable configuration of the actor network helps balance the benefits of social and economic attributes and environmental services generated by the multifunctional agriculture (Musacchio 2009).

\subsection{Structural equation model as an analytical framework}

We propose herein a structural equation model as an analytical framework to analyze the structural relationship of multifunctional agriculture in construction of the actor network. The structural relationship is tested by a structural equation model, which is a multivariate statistical analysis capable of simultaneously measuring concepts generated by confirmatory factor analysis, including pathways of hypothesized relationships between actors (Gross and Brown 2008). As a powerful tool, the structural equation model contributes to estimating direct and indirect relationships among dependent and independent variables by calculating partial regression and correlation coefficients (Wootton 1994). One benefit of this technique is its confirmatory (hypothesis testing) rather than exploratory method (Bagozzi and Yi 2012). The structural equation model can comprehensively represent complex multidimensional relationships among research variables within a multifunctional agriculture actor network.

We intend to (1) test a structural equation model, which is used for testing the structural framework of a multifunctional agriculture actor network in the construction, (2) illustrate the structural relationships among different functions in the construction of the multifunctional agricultural actor network, and (3) provide an analytical framework of a comprehensive evaluation system and land use planning for multifunctional agriculture in sustainable agriculture.

\section{Materials and methods}

\subsection{Study area}

Dalishu Village is in southeastern Liaoning Province, China (Fig. 1). Ecological environmental conditions such as abundant precipitation, dense vegetation, rich water resources, and warm temperatures aid in the development of multifunctional agriculture. 


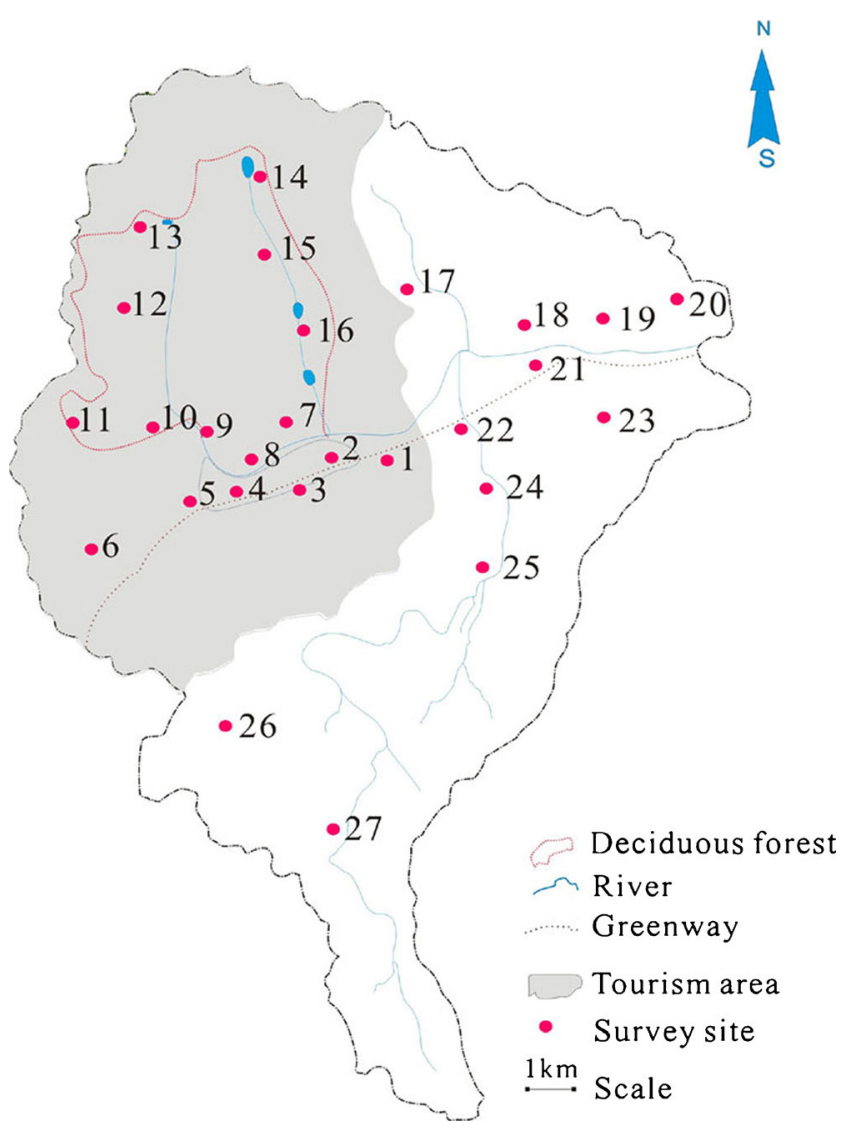

Fig. 1 A map of study site located in the Dalishu village in Liaoning Province, China

For decades, Dalishu Village has been a microcosm of new rural construction and is considered one of the top 100 villages in the country. Multifunctional agriculture attains an equilibrium that results in an economically efficient, socially balanced, and environmentally friendly modern ecological agriculture system in Dalishu. Rural tourism has become an important industry in the village, which earned recognition as a "China Agricultural Park" in 2010 and marked a transition of conventional agriculture to a new stage of multifunctional agriculture (Fig. 2).

In Dalishu Village, multifunctional agriculture has various non-commodity outputs, in addition to organic food production (e.g., fruit and vegetable production). This introduces a new rural landscape configuration for multiple agricultural functions. The most valued aspects of this new configuration are rural tourism and other functions that also achieve equilibrium for multifunctional agriculture in Dalishu. The area of the village was about 4,800 ha in 2009 , of which $59 \%$ comprised multifunctional agriculture uses. Residential area accounts for $2.5 \%$, which embraces some 4,800 inhabitants. Other land uses include new arrangements of multifunctional agriculture, such as ecotourism spots and greenways, representing 4.32 and $1.04 \%$, respectively.

The strategy of "building a new countryside" builds a bridge between landscape space planning and multifunctional

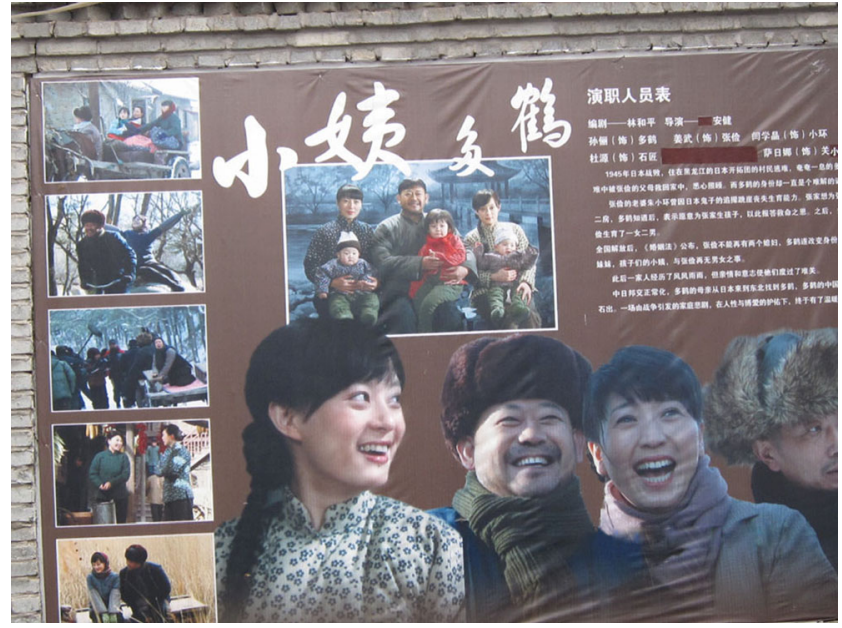

Fig. 2 Sister-in-law multicranes: outdoor base for shooting TV programs and movies in Dalishu village. It also becomes an independent tourism attraction in Dalishu village

agriculture and is intended to coordinate urban and rural development. As an important mode of innovation, rural tourism links the rural landscape to multifunctional agriculture in Dalishu Village. The tourism function is meant to retain traditional society, preserve natural resources, encourage organic agriculture, and integrate rural economic ecosystem services, as an activity essential to the vitality of the village (Fig. 3). Therefore, the tourism function is identified as a potential recreational resource to advance the transition to multifunctional rural landscapes, such as fruit production and crops of Schisandra chinensis (five-flavor berry, a medicinal herb).

Multifunctional agriculture in the village concentrates on conventional agriculture, the farm-produce processing industry, and rural tourism. Conventional agricultural activities are fruit production and crops of $S$. chinensis. Recently, this cultivation in Dalishu was awarded Good Agricultural Practices

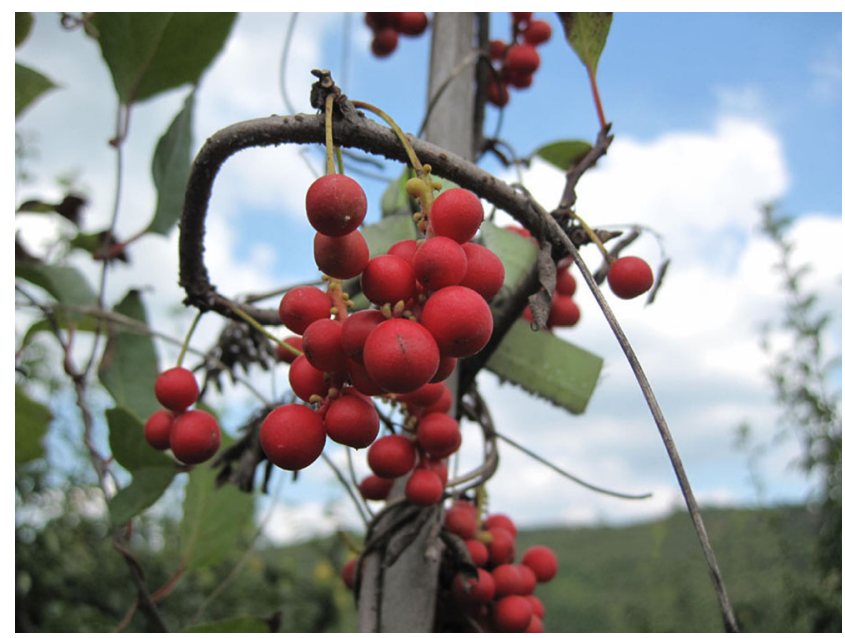

Fig. 3 Crop of five-flavor berries (S. chinensis). It is considered as a medicinal herb, and Dalishu village is a production base of $S$. chinensis in northern China 
certification by the European Union. This certification is a collection of principles applied to on-farm production and postproduction processes, resulting in safe and healthy food and nonfood agricultural products.

The farm-produce processing industry has several characteristics of agricultural products, such as alcoholic beverage production of $S$. chinensis and primary processing products of other agricultural materials. Rural tourism offers a variety of tourist attractions involving a wide range of outdoor and adventure activities, plus dining experiences. Such activities include fruit picking in an eco-orchard, greenway sightseeing, and organic food processing in the village. These activities increase the potential of agricultural and nonagricultural land use, via multifunctional landscape planning. Multifunctional land use aims to make Dalishu a model village of rural experiential tourism in northeast China. From 1995 to 2010, there was an average increase in the number of tourists in Dalishu Village about $20 \%$ annually, and tourism income has risen an average of about $35 \%$ per year (Fig. 4). Currently, the multifunctional rural landscape of Dalishu as a rural tourism attraction receives about 100,000 visitors a year, which stimulates other areas of agricultural growth in the village.

Multifunctional agriculture offers local employment opportunities on plantations, in the farm produce processing industry, and in rural tourism. The employment rate of villagers has steadily increased, and average annual income has increased by $20 \%$ from the 1990 s to 2010 s. Multifunctional agriculture encourages retention of existing local employment and facilitates the promotion of additional employment within the village to an appropriate level. Locally produced farm products are favored as tourist souvenirs.

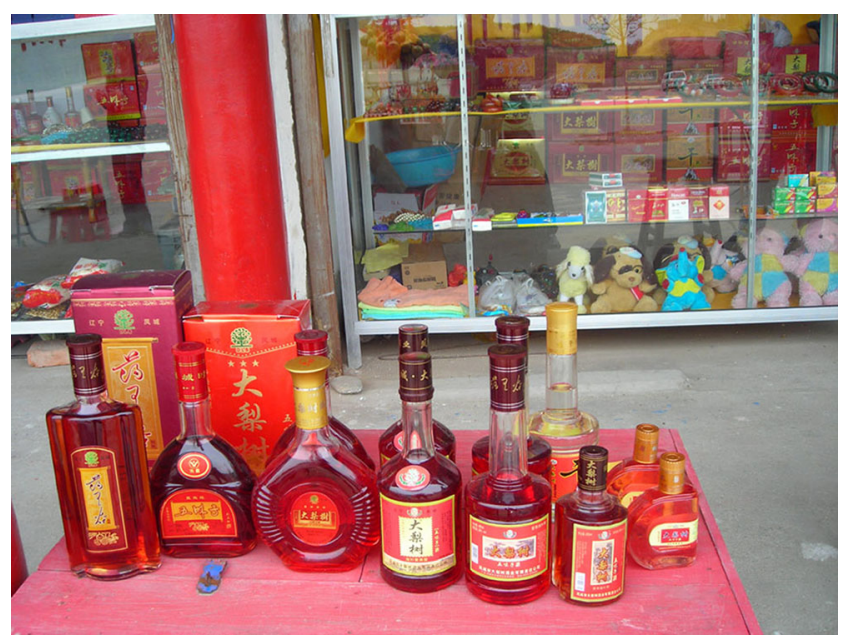

Fig. 4 Wuweizi (S. chisandra) beverage: a processed farm product made from $S$. chinensis in the Dalishu village

\subsection{Data collection}

To test the structural equation model presenting ten theoretical hypotheses $(\mathrm{H})$, we used a two-stage process for data collection. The first stage involved the identification and adaptation of questionnaire measurement scales taken from field investigation in Dalishu Village. These scales were then entered into a questionnaire, which was reviewed by a number of rural eco-industry practitioners and tourists to validate the terminology of the scale relevant to this study. The questionnaire contained 20 questions (observed variable) regarding peoples' perception of various actors (e.g., societal, ecological, industry, tourism, and benefits actors). The perceptions included physical features of the rural landscape, attitudes about the status of rural industrial development, and perceptions of social and sociodemographic information. Sample populations were drawn from three sources, rural residents, tourists, and scholars. The second stage included administration of the questionnaire, to collect data for testing the proposed model. Sample populations were drawn from two sources, tourists and a small number of rural residents.

The data were derived from both primary and secondary sources. Primary data came from the questionnaire survey and participatory observation at research sites. Every site provided a public open space for tourism activities, which closed the relationship to multifunctional agriculture. These sites constructed a spatial multifunctional landscape network through the interaction of multiple functions in sustainable agriculture. Secondary data were obtained from published material, reports, journal articles, and the local forest management system. Based on in-depth interviews and participatory observations of tourists and local villagers, data were collected on their perceptions at the research sites across the rural landscape (average distance between sites was $1.2 \mathrm{~km}$ ). Interviewees were asked about their perceptions of multifunctional agriculture (and its quality) in Dalishu Village. At the same time, personal interviews provided the opportunity to visit local villagers and inquire whether they had adopted sustainable agriculture production systems.

The questionnaires in Chinese were entirely related to multifunctional agriculture, and they were measured using a fivepoint Likert scale, with 1 for "strongly disagree," 2 for "disagree," 3 for "neutral," 4 for "agree," and 5 for "strongly agree." Answers 3, 4, and 5 were considered positive. Questionnaires were distributed to $366(87.5 \%$ of total) tourists from various regions and to $52(12.5 \%)$ local villagers. Respondents were free to answer the questionnaire anonymously.

\subsection{Data analysis}

The observed variables comprise different attributes of multiple functions of multifunctional agriculture in Dalishu 
Village. The variables regarding the actors contain multiple functions of local agricultural production, societal welfare, landscape management, and tourism experiences. Average values were between 3.56 and 3.15 , representing performance perceptions between "agree" (4) and "neutral" (3). Respondents believed that multifunctional agriculture activities performed best in terms of agricultural production, with nonagricultural production, and environmental protection ranked second and third, respectively. At the same time, we conducted a pilot study to evaluate the suitability of the questionnaire for analyzing variable change. Cronbach's alpha values are shown in Table 1 . These observed variables were between 0.66 and 0.85 , indicating measurement reliability of the observed variables.

\subsection{Method}

Our study presents a structural equation model as an analytical framework to ascertain the structural relationship of industrial, ecological, societal, tourism, and benefits functions within the multifunctional agriculture actor network (Fig. 5). The structural equation model incorporates measurement of both observed and latent variables and considers the interaction between constructions of multiple functions in the multifunctional agriculture actor network. The model does not necessarily discover causal relationships, but shows whether the causal assumptions embedded in the model match sampled data (Kirby and Bollen 2009). Complex structural equation models are often easier to understand

Table 1 Characteristics of functional actors as measurement variables for testing structural equation model of multifunctional agriculture actor network theoretical framework for Dalishu Village

\begin{tabular}{|c|c|c|c|c|c|}
\hline Type of Actor & Observed variable & Desirable characteristics and measures (Scale: $1-5$ ) & Mean & SD & $\begin{array}{l}\text { Factor } \\
\text { loading }\end{array}$ \\
\hline \multirow[t]{4}{*}{$\begin{array}{l}\text { Societal actor (Cronbach's } \\
\quad \alpha=0.68)\end{array}$} & Accessibility & $\begin{array}{l}\text { Satisfaction among tourists and local residents on convenience of } \\
\text { rural roads }\end{array}$ & 3.33 & 0.92 & 0.70 \\
\hline & Rurality & $\begin{array}{l}\text { Traditional features of low population density and much of the } \\
\text { land for agriculture }\end{array}$ & 3.42 & 0.92 & 0.18 \\
\hline & Folk custom & $\begin{array}{l}\text { People can perceive real rural life and folk customs by staying and } \\
\text { participating }\end{array}$ & 3.20 & 1.01 & 0.23 \\
\hline & $\begin{array}{l}\text { Architecture } \\
\text { features }\end{array}$ & Local characteristics of rural traditional architecture & 3.35 & 0.96 & 0.70 \\
\hline \multirow[t]{4}{*}{$\begin{array}{l}\text { Ecological Actor (Cronbach's } \\
\quad \alpha=0.81)\end{array}$} & Ecological stability & $\begin{array}{l}\text { Degree of stability when the ecosystem suffers from small short- } \\
\text { lived disturbances }\end{array}$ & 3.61 & 0.89 & 0.69 \\
\hline & $\begin{array}{l}\text { Ecological } \\
\text { agriculture }\end{array}$ & $\begin{array}{l}\text { Practice of sustainable farming and rural environment coordinated } \\
\text { development }\end{array}$ & 3.23 & 1.08 & 0.79 \\
\hline & Land Use intensity & $\begin{array}{l}\text { Extent to which land is used for sustainable development in the } \\
\text { rural area }\end{array}$ & 3.55 & 0.99 & 0.74 \\
\hline & Protection measures & $\begin{array}{l}\text { Policies and regulations to improve rural ecological environmental } \\
\text { protection }\end{array}$ & 3.54 & 0.96 & 0.78 \\
\hline \multirow[t]{4}{*}{$\begin{array}{l}\text { Industrial Actor (Cronbach's } \\
\qquad \alpha=0.66)\end{array}$} & $\begin{array}{l}\text { Community } \\
\text { involvement }\end{array}$ & $\begin{array}{l}\text { Levels of community involvement in agro-eco-economics system } \\
\text { development }\end{array}$ & 3.26 & 1.01 & 0.73 \\
\hline & Leading industries & $\begin{array}{l}\text { Agro-eco-economics system can play an important role in rural } \\
\text { development }\end{array}$ & 3.52 & 0.91 & 0.17 \\
\hline & $\begin{array}{l}\text { Regional } \\
\text { advantages }\end{array}$ & $\begin{array}{l}\text { Agro-eco-economics system development has regional } \\
\text { competition advantages }\end{array}$ & 3.46 & 0.86 & 0.19 \\
\hline & Economic vitality & $\begin{array}{l}\text { Rural ecosystem will add to the economic vitality of rural area } \\
\text { development }\end{array}$ & 3.28 & 0.99 & 0.30 \\
\hline \multirow[t]{4}{*}{$\begin{array}{l}\text { Tourism Actor (Cronbach's } \\
\alpha=0.85 \text { ) }\end{array}$} & $\begin{array}{l}\text { Educational } \\
\text { experience }\end{array}$ & $\begin{array}{l}\text { Vernacular knowledge offered by people participating in the rural } \\
\text { activity }\end{array}$ & 3.35 & 1.02 & 0.74 \\
\hline & $\begin{array}{l}\text { Esthetics } \\
\quad \text { experience }\end{array}$ & Esthetic qualities offered by different types of rural activity & 3.34 & 0.99 & 0.78 \\
\hline & $\begin{array}{l}\text { Entertainment } \\
\text { experience }\end{array}$ & $\begin{array}{l}\text { Enjoying entertainment benefits offered by different types of rural } \\
\text { activity }\end{array}$ & 3.33 & 1.02 & 0.78 \\
\hline & Escapist experience & $\begin{array}{l}\text { Immersion and active participation offered by different types of } \\
\text { rural activity }\end{array}$ & 3.28 & 1.03 & 0.76 \\
\hline \multirow{4}{*}{$\begin{array}{l}\text { Benefits Actor (Cronbach's } \\
\quad \alpha=0.76)\end{array}$} & Economic benefit & Economic benefits offered by different types of rural activities & 3.56 & 1.06 & 0.76 \\
\hline & Ecological benefit & Ecological benefits offered by different types of rural activities & 3.33 & 0.97 & 0.73 \\
\hline & Social Benefit & Social benefits offered by different types of rural activities & 3.43 & 1.02 & 0.82 \\
\hline & Individual benefit & Individual benefits offered by different types of rural activities & 3.15 & 1.09 & 0.42 \\
\hline
\end{tabular}

Significant at $\alpha=0.01$ level. Mean score of actor perception for respondents was $3.38 \pm 0.22(P<0.01)$; SD (standard deviation) was $0.98 \pm 0.11$ $(P<0.01)$ 
Fig. 5 Multifunctional agriculture actor network theoretical framework. Structural equation model is used as an analytical framework to recognize ten hypotheses of structural relationship of actor network

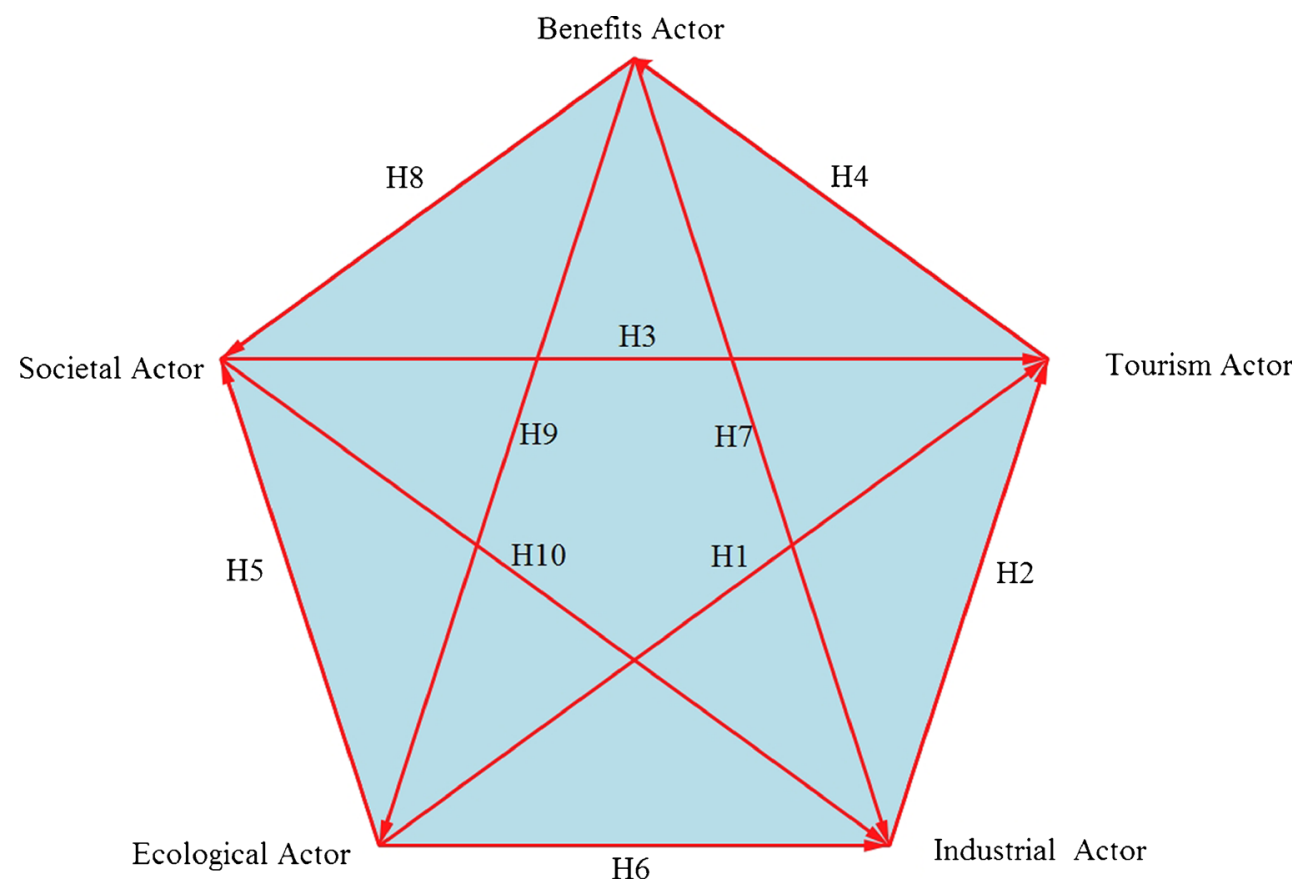

when they are expressed as path diagrams rather than equations.

To establish a comprehensive structural relationship between the multiple functions in a multifunctional agriculture actor network, we propose the following ten hypotheses.

Hypothesis 1 The ecological actor has an effect on the tourism actor.

Hypothesis 2 The industrial actor has an effect on the tourism actor.

Hypothesis 3 The societal actor has an effect on the tourism actor.

Hypothesis 4 The tourism actor has an effect on the benefits actor.

Hypothesis 5 The ecological actor has an effect on the societal actor.

Hypothesis 6 The ecological actor has an effect on the industrial actor.

Hypothesis 7 The benefits actor has an effect on the societal actor.

Hypothesis 8 The benefits actor has an effect on the industrial actor.

Hypothesis 9 The ecological actor has an effect on the benefits actor.

Hypothesis 10 The societal actor has an effect on the industrial actor.

These hypotheses were used to construct the structural equation model for revealing the structural relationships of the multifunctional agriculture actor network. Actors in these hypotheses represent a single functional type of multifunctional agriculture in rural areas. We used the statistical program analysis of moment structures (AMOS, version 6.0) (Arbuckle 1994) to test the structural equation model framework.

\section{Result and discussion}

\subsection{Analysis of structural model}

First, our findings suggest that the structural equation model is non-recursive and contains at least one feedback loop. The existence of such loops in a non-recursive model may make the model system unstable. To measure stability of the proposed model, we used a stability index (Bentler and Freeman 1983). When the stability index is within -1 and +1 , the model is stable. The stability index of our model was 0.54 , so the non-recursive characteristic is acceptable. The model represents a theoretical framework of the actor network, which attains a state of equilibrium in the dynamic interaction of multifunctional agriculture.

Second, our findings imply that the path coefficients (estimates of standardized regression weights) comprehensively support all $\mathrm{H}$. This suggests a weak association between the ecological actor and tourism functions $\left(\beta_{1}=0.14\right)$ (H1) and indicates a positive association between the industrial actor and tourism functions $\left(\beta_{2}=0.32\right)(\mathrm{H} 2)$. Also demonstrated is a weak positive relationship $\left(\beta_{3}=0.24\right)$ between the societal actor and tourism functions (H3) and a positive relationship between the tourism and benefits functions 
$\left(\beta_{4}=0.83\right)(\mathrm{H} 4)$. Other significant path estimates $\left(\beta_{5}=0.32\right.$, $\beta_{6}=0.69, \beta_{7}=0.11, \beta_{8}=0.13, \beta_{9}=0.76$, and $\beta_{10}=0.18$ ) support $\mathrm{H} 5$ through H10. As shown in the model, every actor affects the multifunctional agriculture actor network, either directly or indirectly. This means that the industrial function effect on the tourism function is strong, which indicates that the industrial function is the major driver of the multifunctional agriculture actor network in Dalishu Village.

Third, our findings show that effects of some functions on variables are unbalanced, or that there are functional differences within the multifunctional agriculture actor network. The factor loading $(0.79)$ between industrial actor effects on economic vitality is very clear. This indicates a strong effect of the industrial function on economic vitality, which is dominant in the village. In the societal function effect on variable rurality (a rural characteristic or trait) and folk custom features, the factor loadings are 0.18 and 0.23 , respectively. This means that rurality and folk customs are weakly affected by the societal function, indicating that the social function is relatively stable in the development of multifunctional agriculture. The results suggest that all standardized factor loadings are statistically significant. The coefficient of every indicator was from 0.17 to 0.82 .

Finally, the findings suggest some weak links in the multifunctional agriculture actor network, such as for H1, $\mathrm{H} 7, \mathrm{H} 8$, and H10. The significance of weak links is a greater likelihood of bridging, relative to strong links in the network (Granovetter 1983). Weak links more likely bring innovative ideas than strong connections because the heterogeneous conditions created when various forms of knowledge and capabilities intersect are more likely to produce novel recombination in the actor network. This means that it may integrate innovations that strengthen the ecological function effect on the tourism function (H1), the benefits effect on both the societal (H7) and industrial (H8) functions, and societal function effect on industrial function. Therefore, weaker links between the multiple functions in the multifunctional agriculture actor network may transform into an innovative bridge for sustainable agriculture in the rural area.

\subsection{Goodness-of-fit of structural model}

Assessment of fit is a basic task in the structural equation model, forming the basis for accepting or rejecting models and for accepting one competing model over another (Crowley and Fan 1997). Commonly used goodness-of-fit indices all met generally recommended threshold levels, including $\chi^{2} / \mathrm{df}=2.24(373.996 / 167)\left(\chi^{2}\right.$ is the chi-squared test; df is degrees of freedom), Bentler's comparative fit index $=0.93$, Tucker - Lewis index $=0.92$, and root mean square error of approximation $=0.055$. This shows that the overall measurement model appeared to fit the data reasonably. The fit per degree of freedom of the model is expressed by the root mean square error of approximation. Values of the latter less than 0.08 imply an acceptable model fit, and values less than 0.05 imply a good fit (Bentler 1990).

\subsection{Discussion}

This work helps clarify the specific role and position of the multiple functions in construction of the multifunctional agriculture actor network. An advantage of the framework is that it takes construction of the actor network as the central object of multifunctional agriculture, rather than individual market or nonmarket functions. Another advantage is that every action of a functional actor within the actor network is a networking behavior of multifunctional agriculture. As a basis of land use planning for sustainable agriculture, the actor network framework can assist rural managers to identify structural relationships of multifunctional land use planning. The network can predict the potential of every functional actor and contribute to a comprehensive evaluation system for formulating regulatory mechanisms in multifunctional agriculture.

Nonmarket functions are closely interrelated with various market functions of the rural ecosystem, which is linked to rural social life, environmental conservation, and agricultural production. In the actor network, scores of the tourism function for rurality, regional advantages, and leading industries are greater than those of other observed variables, despite the factor loading between main actors being relatively small. This means that rural characteristics, folk customs, and leading industries could maintain a normal situation and be less affected by the other factors within the multifunctional agriculture actor network. These factors still affect values creation in the rural tourism sector, including community participation and tourist involvement as resources. Therefore, these observed variables are still indispensable components of the actor network.

The new paradigm of the multifunctional agriculture actor network helps to test the causal relationship between multiple functions for adjusting agricultural ecological measures and the formulation of a comprehensive evaluation system, which effectively promotes multifunctional land use planning for sustainable agriculture. The implementation of measures should consider the scales of the agricultural ecological environment. These include the spatial scales of nonagricultural land use that can be structured into multifunctional clusters with the performance objective of multifunctional agriculture in rural areas. In addition, nonagricultural land use relates to the socioeconomic status, cultural complex, and past tourism experiences of the tourist, which influence the quality of the constructed multifunctional agriculture actor network. Further research is required to more accurately characterize the roles of other factors (actors) in the formation of that network. 


\section{Conclusion}

The actors in our multifunctional agriculture actor network come from the social and natural sciences, which are symbols of both market and nonmarket functions of sustainable agriculture. Through interaction, these functions transfer into one another within network construction. This aids the construction of a comprehensive assessment system for multifunctional land use. As a new paradigm, the actor network represents an understanding of the dynamics, plus ecological, social, and economic values of services in multifunctional agriculture. The framework creates an ongoing dynamic structural relationship between multiple functions, and reveals that public stakeholders have the capacity to formulate solutions for weak links in the network toward sustainable development.

The construction of the multifunctional agriculture actor network has increased the annual average income by $20 \%$ (over 1990-2010) in Dalishu Village. As a basis of this network, the ecological function determines the strength of the economic, societal, and tourism functions through levels of conservation in the rural ecological environment. This scheme contributes to the construction of the network, which strengthens the ecological function effect on the tourism function, the benefits effect on the societal function, benefits effect on the industrial function, and societal function effect on the industrial function. The greatest possible benefit to the ecological function can be achieved through the benefits adjustment mechanism in the actor network. The construction of this network is an innovation in integration, and not only considers individual benefits of each type of innovation alone, but also highlights powerful synergies that can be realized by aligning all types.

Each functional action of the multifunctional agriculture actor network is distributed extensively in the multifunctional landscape and affects geographic space and sociological relationships of the rural area. The tourism function is a basis of rural recreational experience that can be used to design the creative space, which integrates multiple functions of the rural landscape and the potential of multifunctional agriculture. Therefore, the tourism function is a type of relational space of actor interaction, which enhances the innovative integration of agricultural ecological activities. At the same time, enhancing the function of rural tourism by increasing agritourism land improves the comprehensive values of the multiple functions, which may serve as a basis for rural landscape planning and multifunctional agriculture.

Acknowledgments This project was funded by the National Natural Science Foundation of China (NSFC 40871005, 40871062), Educational Commission of Liaoning Province (no. W2010158), and the Social Sciences Research Fund of Liaoning Province (L11BJL024). We thank Drs. Daolan Zheng and Weihong Fan for valuable comments on an earlier version of this manuscript. We would also like to emphasize our gratitude to the anonymous reviewers and editorial staff of the journal for their contributions.

\section{References}

Arbuckle JL (1994) Computer announcement amos: analysis of moment structures. Psychometrika 59:135-137

Baggio R, Scott N, Cooper C (2010) Network science: a review focused on tourism. Ann Tourism Res 37:802-827. doi:10.1016/j.annals. 2010.02.008

Bagozzi RP, Yi Y (2012) Specification, evaluation, and interpretation of structural equation models. J Acad Market Sci 40:8-34. doi:10. 1007/s11747-011-0278-x

Bentler PM (1990) Comparative fit indexes in structural models. Psychol Bull 107:238-246. doi:10.1037/0033-2909.107.2.238

Bentler PM, Freeman EH (1983) Tests for stability in linear structural equation systems. Psychometrika 48:143-145

Comber A, Fisher P, Wadsworth R (2003) Actor-network theory: a suitable framework to understand how land cover mapping projects develop? Land Use Policy 20:299-309. doi:10.1016/S02648377(03)00048-6

Crowley SL, Fan X (1997) Structural equation modeling: basic concepts and applications in personality assessment research. J Pers Assess 68:508-531. doi:10.1207/s15327752jpa6803_4

Dessein J, Bock BB, de Krom MP (2013) Investigating the limits of multifunctional agriculture as the dominant frame for Green Care in agriculture in Flanders and the Netherlands. J Rural Stud 32:50 59. doi:10.1016/j.jrurstud.2013.04.011

Granovetter M (1983) The strength of weak ties: a network theory revisited. Sociol Theor 1:201-233

Granvik M, Lindberg G, Stigzelius K-A, Fahlbeck E, Surry Y (2012) Prospects of multifunctional agriculture as a facilitator of sustainable rural development: Swedish experience of Pillar 2 of the Common Agricultural Policy (CAP). Norsk Geografisk 66:155166. doi:10.1080/00291951.2012.681684, Tidsskrift-No

Gross MJ, Brown G (2008) An empirical structural model of tourists and places: progressing involvement and place attachment into tourism. Tourism Manage 29:1141-1151. doi:10.1016/j.tourman. 2008.02.009

Kirby JB, Bollen KA (2009) Using instrumental variable tests to evaluate model specification in latent variable structural equation models. Sociol Methodol 39:327-355

Law J (1992) Notes on the theory of the actor network: ordering, strategy, and heterogeneity. Systems Practice 5:379-393. doi:10. 1007/BF01059830

Le Bellec F, Rajaud A, Ozier-Lafontaine H, Bockstaller C, Malezieux E (2012) Evidence for farmers' active involvement in codesigning citrus cropping systems using an improved participatory method. Agron Sustain Dev 32:703-714. doi:10. 1007/s13593-011-0070-9

Lichtfouse E, Navarrete M, Debaeke P, Souchère V, Alberola C, Ménassieu J (2009) Agronomy for sustainable agriculture: a review. Agron Sustain Dev 29:1-6. doi:10.1051/agro:2008054

Long H, Liu Y, Li X, Chen Y (2010) Building new countryside in China: a geographical perspective. Land Use Policy 27:457470

Malézieux E (2012) Designing cropping systems from nature. Agron Sustain Dev 32:15-29. doi:10.1007/s13593-011-0027-z

Marsden T, Sonnino R (2008) Rural development and the regional state: denying multifunctional agriculture in the UK. J Rural Stud 24:422-431. doi:10.1016/j.jrurstud.2008.04.001

Murdoch J (2000) Networks - a new paradigm of rural development? J Rural Stud 16:407-419. doi:10.1016/S0743-0167(00)00022-X

Musacchio LR (2009) The scientific basis for the design of landscape sustainability: a conceptual framework for translational landscape research and practice of designed landscapes and the six Es of landscape sustainability. Landscape Ecol 24:993-1013. doi:10. 1007/s10980-009-9396-y 
Noe E, Alrøe HF, Langvad AMS (2008) A polyocular framework for research on multifunctional farming and rural development. Sociol Ruralis 48:1-15. doi:10.1111/j.1467-9523.2008.00451.x

Refsgaard K, Johnson TG (2010) Modeling policies for multifunctional agriculture and rural development - a Norwegian case study. Environ Policy Gov 20:239-257. doi:10.1002/eet.549

Renting H, Rossing W, Groot J, Van der Ploeg J, Laurent C, Perraud D, Stobbelaar DJ, Van Ittersum M (2009) Exploring multifunctional agriculture. A review of conceptual approaches and prospects for an integrative transitional framework. J Environ Manage 90:S112S123. doi:10.1016/j.jenvman.2008.11.014

Rossing W, Zander P, Josien E, Groot J, Meyer B, Knierim A (2007) Integrative modeling approaches for analysis of impact of multifunctional agriculture: a review for France, Germany, and The Netherlands. Agr Ecosyst Environ 120:41-57. doi:10.1016/ j.agee.2006.05.031

Steen J (2010) Actor-network theory and the dilemma of the resource concept in strategic management. Scand J Manage 26:324-331. doi:10.1016/j.scaman.2010.05.003

Van der Duim R (2007) Tourismscapes an actor network perspective. Ann Tourism Res 34:961-976. doi:10.1016/j.annals.2007.05.008

Wilson GA (2009) The spatiality of multifunctional agriculture: a human geography perspective. Geoforum 40:269-280

Wootton JT (1994) Predicting direct and indirect effects: an integrated approach using experiments and path analysis. Ecology $75: 151-165$ 